\title{
Control in Fiscal Responsibility - Two Roads to the Same Goal
}

\author{
Marijana Cupać \\ Assistant Mayor, Trg slobode 1, Subotica, Serbia, marijana.cupac@subotica.rs \\ Saša Gravorac \\ Internal Audit, internal audit service, Trg slobode 1, Subotica, Serbia, sasa.gravorac@subotica.rs \\ Dejan Gligović \\ Modern Business School, Assistant professor, Terazije 27, Belgrade, Serbia, dejan.gligovic@mbs.edu.rs \\ Goran Šijan \\ University of Novi Sad, Assistant with doctorate, Faculty of economics, Segedinski put 9 -11, Subotica, \\ Serbia, goransijan70@gmail.com
}

Received (11.12.2018.); Revised (19.01.2019.); Accepted (14.02.2019.)

\begin{abstract}
The process of privatization and Serbia's determination to join the European Union, as well as the growing economic crisis and market competition as factors of an exogenous nature, have imposed both the need for the creation of an instrument in front of the private sector as well as before the public sector that will overcome the growing market challenges, which are inevitably posed both to private entities and to public sector entities. Apart from their basic role, which is reflected in the provision of quality services to their main consumers - the population, the demands of higher fiscal authorities for saving, increasing the efficiency and effectiveness of operations, as well as for achieving profit, are increasingly placed before the management of public enterprises. Quality of services provided. Increasing public sector orientation towards the market principles of business has imposed on the public sector the implementation of some traditional market mechanisms that are used in the function of raising the overall profitability of the business, and hence the demand for permanent education of management and employees in the function of mastering and implementing traditional market instruments in the direction of greater efficiency of public enterprises. The paper will analyze the concept and characteristics of the public sector, the basic nature and the essence of controlling, the process of implementation of controlling in public sector entities, and the level of development of controlling in the public sector of the Republic of Serbia.
\end{abstract}

Key words: public sector, fiscal responsibility, controlling, efficiency, performance

\section{INTRODUCTORY CONSIDERATIONS}

Controlling in the Republic of Serbia is in the initial stage of development, while controlling in the public sector is at the very beginning of implementation in public sector entities. Today, besides the private sector entities and public sector entities, there is a growing need for permanent improvement in the performance of their business, and the presumption of achieving this goal is to provide reliable and accurate data of substantiated information. Strategic decision-making of public sector entities' management is the prerequisite for achieving efficiency, effectiveness and economy of the public sector as a set of important goals in its business, and this is precisely the way in which controlling is an important instrument of support to the management of public sector entities in the planning, decisionmaking processes and in the whole management process. Certainly, controlling in the public and private sectors has significant differences, which arise from the very nature of the public sector. Implementation of public sector control in domicile business conditions is extremely important, since the public sector represents a significant segment of the overall market environment in the Republic of Serbia. Certainly, in the conditions when the public sector is an essential element of the market, the improvement of its efficiency, effectiveness and cost-effectiveness will ensure a significant improvement in the quality of the overall economic environment, and thus ensure the preconditions for smooth market and social development and create good "supportive" 
foundations for a better positioning of domicile economy in international economic relations.

\section{PUBLIC SECTOR - SOCIAL PROGRESS FACTOR IN THE MARKET VS MARKET SOURCE}

In less developed countries, the public sector, in most cases, has an extremely important place in the overall economic sphere, and very often appears as the most important employer. Since Serbia belongs to the less developed countries, which is in the process of transition, the public sector and in domicile business conditions represents a significant segment of the overall market environment, and we will analyze the basic concepts related to the role, significance and functioning of the public sector. When talking about the public sector, it is necessary to point out that according to the Statistics of the State finances of the International Monetary Fund, it is composed of the general government (structured from all the units that are the primary goal and the task of providing public services to the population), then from the segment of public enterprises and the segment of quasi-public enterprises. In order to provide a more comprehensive presentation of the public sector structure, we will use the graphic representation below:

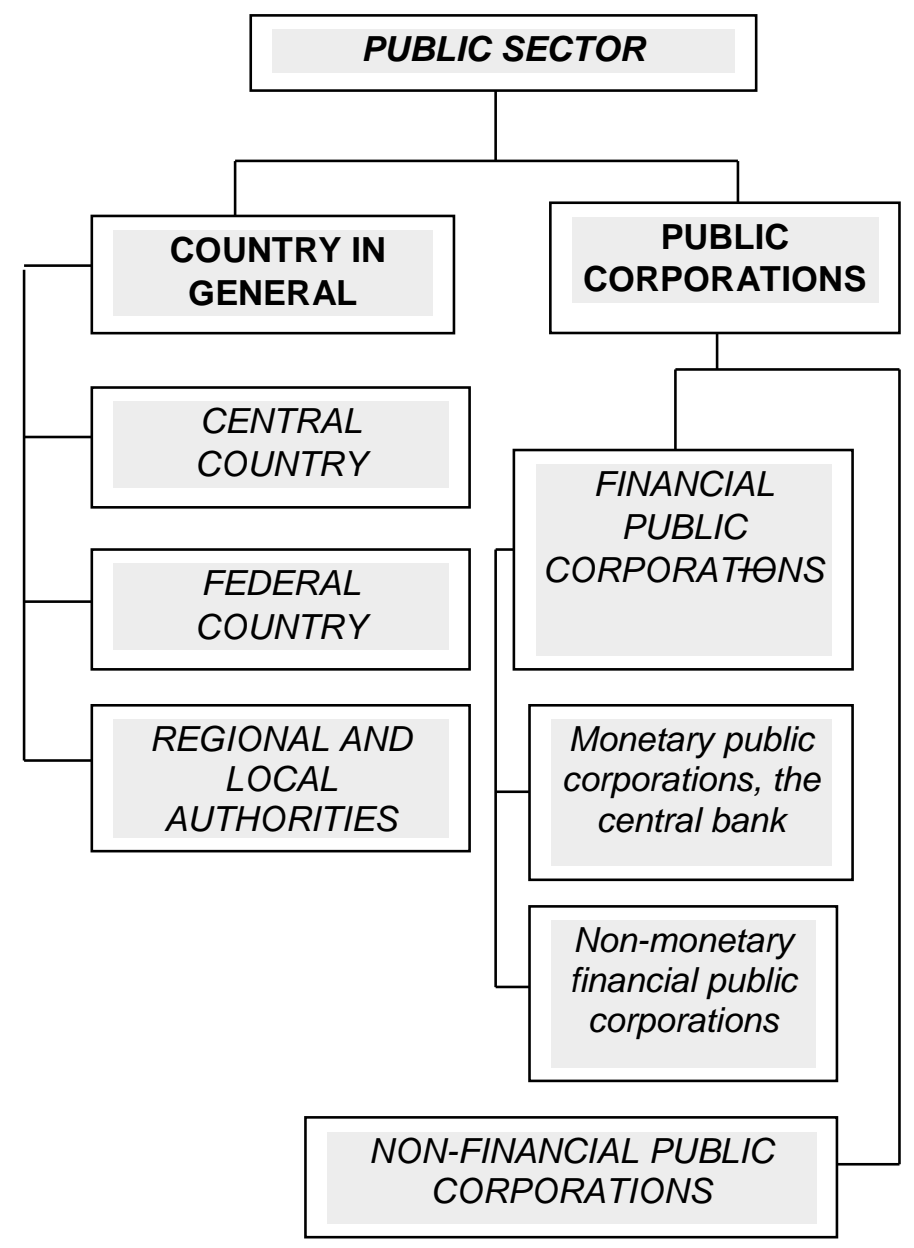

Figure 1. Structure of the public sector [3]
Analyzing the previous graphic presentation, we note that the public sector is structured from the general state and public corporations. Within the general state, we distinguish the central state, the federal state, and regional and local authorities. Also, it is important to emphasize that the segment of the general state is a matter of both national and subnational units within which we can identify extra-budgetary funds. In the local government segment, it implied certain units of government formed on the basis of an administrative division of the state, based on certain political objectives of the government, as well as the geographical differences of particular areas. In the domain of public corporations, we identify primarily financial and non-financial public corporations. Within financial public corporations, we see monetary public corporations and non-monetary public financial corporations.

It is important to note that the public sector is very often the main source of inefficiency in the market environment, because very often the state is not able to achieve the defined goals, and as Stiglic states, we can look for the reasons for this in the following [13] : (1) Limited information - the public sector has significant difficulties in collecting information about the intentions of market participants, which would be an input for the planning of a public offering; (2) Limited control of private market reactions - there is a high degree of constraint in the functioning of the state in order to direct the consequences of its measures, primarily due to the complexity of the market; (3) Limited control over bureaucracy - often bureaucratic institutions do not follow public interest, but their own interests or interests of related groups; and (4) Limitations imposed by political processes politicians are often prone to corruption, as well as acting in the direction of their own or with related stakeholders, and also in order to ensure long-term participation in the government, work towards the implementation of populist measures.

Modern market trends require a higher degree of efficiency in the functioning of the market economy, and also the public sector as one of the most important segments of the modern market environment. In such circumstances, a permanent task is set in front of the public sector in terms of improving the efficiency, effectiveness and economy of operations, and the question of its efficiency is becoming increasingly questionable. Analyzing the theoretical considerations of the methods for measuring the efficiency of the public sector as the basic method, the following three are identified: (1) cost - benefit (implies measuring the efficiency through the consideration of costs incurred in the production of certain benefits, ie goods and services of the public sector, evaluation of the profitability of investment projects) and cost effectiveivess analysis (the essence of this analysis is to compare the effects of different investment projects, ie in the function of choosing 
between different variants of investment projects); (2) Data acquisition analysis - is a technique based on measuring the degree of efficiency of complex entities and allows the analysis to be conducted on the basis of comparing different combinations of variables to be compared and (3) Socio-economic analysis - involves the consideration of different types of indicators that affect the public sector, ie its performances such as: state administration, health system, education system, infrastructure facilities, economic performances, etc.

When looking at the public sector of the Republic of Serbia, we can notice that the major areas in which public sector entities operate are primarily in the following areas [9]: (1) Infrastructure sector (electricity, railway, PTT, radio, television, air traffic); (2) Communal activities; and (3) Other activities of general and strategic importance for the Republic of Serbia, as well as activities necessary for the work of state bodies (individual agencies) and bodies of the local self-government unit. Furthermore, it should be pointed out that the public sector is of great importance for the Republic of Serbia, as best evidence of the following data is best shown:

Table 1. Indicators of importance of the public sector of the Republic of Serbia [16]

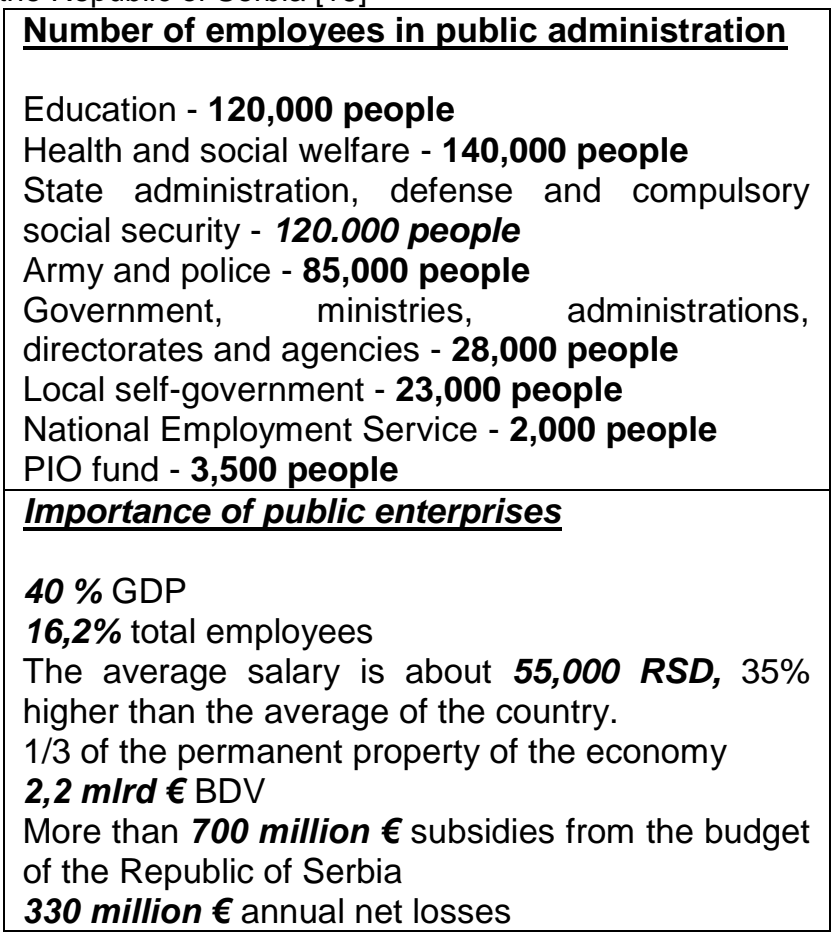

Analyzing Table 1, we note that the role of the public sector in the Republic of Serbia is extremely important, both in terms of the number of employees moving at the level of 521,500 people, as well as the share of the public sector in GDP at the level of $40 \%$. Public sector subsidies range from $€ 700$ million, with net losses at an annual level of $€ 330$ million. If we consider the above data, we can with a high degree of security confirm that the public sector has an extremely important place in the domicile economic system.

In order to point to the current state of the public sector in the Republic of Serbia, in the following table, we will list the most relevant economic categories in the period from 2013 to 2018, based on the following data:

Table 2. Overview of economic trends in the Republic of Serbia [15]

\begin{tabular}{|l|l|l|l|l|l|l|}
\hline Indicator & $\mathbf{2 0 1 3}$ & $\mathbf{2 0 1 4}$ & $\mathbf{2 0 1 5}$ & $\mathbf{2 0 1 6}$ & $\mathbf{2 0 1 7}$ & $\mathbf{2 0 1 8}$ \\
\hline $\begin{array}{l}\text { Real GDP } \\
\text { growth rate } \\
\text { (\%) }\end{array}$ & 2,9 & $-1,6$ & 1,8 & 3,3 & 2,0 & 4,4 \\
\hline $\begin{array}{l}\text { Private } \\
\text { consumption } \\
\text { (\%) }\end{array}$ & $-1,7$ & $-0,1$ & $-0,3$ & 1,3 & 1,9 & 3,5 \\
\hline $\begin{array}{l}\text { Private } \\
\text { investment (\%) }\end{array}$ & $-7,7$ & $-5,6$ & 3,5 & 2,7 & 10,1 & 9,4 \\
\hline $\begin{array}{l}\text { Government } \\
\text { spending (\%) }\end{array}$ & $-2,1$ & 0,9 & $-3,7$ & 1,2 & 3,3 & 5,1 \\
\hline $\begin{array}{l}\text { Government } \\
\text { investments } \\
\text { (\%) }\end{array}$ & $-35,8$ & 13,6 & 14,0 & 22,0 & $-6,4$ & 22,4 \\
\hline Export (\%) & 18,0 & 4,3 & 9,4 & 11,9 & 8,2 & 9,3 \\
\hline Import (\%) & 6,5 & 5,1 & 4,0 & 6,7 & 11,1 & 10,0 \\
\hline $\begin{array}{l}\text { Unemployment } \\
\text { rate (\%) }\end{array}$ & 22,1 & 19,2 & 17,7 & 15,3 & 13,5 & 11,3 \\
\hline $\begin{array}{l}\text { Nominal } \\
\text { earnings (\%) }\end{array}$ & 6,2 & 1,4 & $-0,2$ & 3,7 & 3,9 & -- \\
\hline $\begin{array}{l}\text { Money supply } \\
\text { (M3) in\% }\end{array}$ & 4,6 & 7,6 & 6,6 & 11,6 & 3,6 & --- \\
\hline $\begin{array}{l}\text { Consumer } \\
\text { Price Index } \\
\text { (\%) }\end{array}$ & 2,2 & 1,7 & 1,5 & 1,6 & 3,0 & 2,0 \\
\hline $\begin{array}{l}\text { NBS reference| } \\
\text { interest rate } \\
\text { (\%) }\end{array}$ & 9,5 & 8,0 & 4,5 & 4,0 & 3,5 & 3,0 \\
\hline $\begin{array}{l}\text { Current } \\
\text { Account Deficit } \\
\text { BPM - 6 (\%) }\end{array}$ & 5,8 & 5,6 & 3,5 & 2,9 & 5,2 & 5,2 \\
\hline
\end{tabular}

Table 2 illustrates the movement of the most important economic categories illustrating the economic environment of the Republic of Serbia in the past 6 years. On the basis of the given table, we note that the GDP growth rate was expressed as a percentage of $2.9 \%$ in 2013, then $1.8 \%$ in 2015 , while the estimate for 2018 is that the rate of economic growth will be at the level from $4.4 \%$. In the given period, the unemployment rate ranged to $22.1 \%$ in 2013, while in 2015 it was $17.7 \%$, while the estimate that the unemployment rate in 2018 will be $11.3 \%$. Also, one of the important indicators of economic trends is the consumer price index, which in the observed period was at the level of $2.2 \%$ in 2013 , then at the level of $1.5 \%$ in 2015 , while the consumer price index in 2018 it was $2 \%$.

When looking at the public sector in the Republic of Serbia, one of the priority goals is the process of its restructuring.

Through the process of restructuring the economy, the conditions for improving the overall market conditions, ie for economic growth and development and better positioning of the 
domicile economy in international economic trends, are being created. In this regard, before the restructuring of the public sector in the Republic of Serbia, the following tasks are set [5]: (1) Public sector corporation; (2) Introduction and greater representation of public-private partnerships; (3) Partial privatization and liquidation of state-owned enterprises; (4)

Restructuring and privatization of large public enterprises from infrastructure activities; and (5) Harmonization of domicile regulations and standards with EU acquis.

\section{CHECKING - ADMISSION OR NEED OF A MODERN ENTERPRISE}

Contemporary business operations are reflected in prominent market competition and increasingly turbulent business environment. In such circumstances, controlling, as a form of management activity, is gaining importance, especially when one takes into account that the survival of a modern enterprise can not be imagined without anticipation and timely adjustment to market trends. In the very essence of controlling is the observation of the entire business of the company, but it should not be neglected the fact that its integral and extremely important part is strategic planning and analysis. Through the establishment of a controlling function in modern companies, preconditions for better information support are created for the management of the company, which improves the degree of its adaptability to new market trends.

When it comes to control, it should be emphasized that strategic planning is still at its core as an important factor in the success of the overall business. In such circumstances, the importance of controlling is irreplaceable, and is reflected in some of the following trends:

permanent and timely information management on current market trends; controlling seeks to observe the business of the company through the collaboration of the following key factors such as the adequate creation of the business strategy, the tendency for the business to be sustainable in the long run and that risk assessment is based on objective facts and certainly a specific contribution of controlling in ensuring the fruit of growth, development and profit of the company. Controlling is precisely the essential prerequisite for their long-term balance, which is certainly a presumption of survival and good market positioning of a modern enterprise. In fact, controlling is nothing more than the first signal that should point to the imbalance in the company's operations, enable corrective actions to be undertaken and, ultimately, to improve the overall business operations of the company.
In order to understand controlling it is necessary to analyze the view of Albrecht Deyhleu who thinks that controlling is the following three components [16]: target-oriented management, controllers and managers acting as an important factor and interaction. In fact, "controlling is one of the most important functions whose task is to solve specific problems of enterprise adapting to the internal and external changes that come in.

The task of functional control is to take care of transparent observations and statements of realized revenue, costs, and results achieved as a prerequisite for successful management enterprise" [13].

Controlling should work in support of business processes, and this is especially evident through the security of the so-called. economic transparency in terms of ensuring the information availability of the strategy, business results, and financial processes in the company.

Certainly one of the key challenges posed before controlling is to ensure the reliability of data and proper use by employees in the enterprise.

Controlling should allow for adequate management of the planning process on the one hand, and, on the other hand, to have a proactive role in the development of the content of plans. In fact, we can point out that controllers play a role in ensuring the proactive interaction of all participants in the planning process.

Lately, controllers have increasingly played a role in providing advisory or consulting services related to the process of managing and improving the quality of business decisions made. Controlling is very useful help in the investment decision process [10].

From the aforementioned forms of controlling functions, its functions are also derived.

First of all, controlling has a planning function (it means making decisions towards future results, that is, adapting to the increasingly turbulent business environment as a prerequisite for quality market positioning of the company), then it is important to point to the control function of controlling (the role of controlling is reflected in ensuring the objectivity of control results, control and verification of results obtained by the control process and, finally, the records of data obtained through the control process) and the information control function (this control function is extremely important and is reflected in the importance of information for modern business).

Through informative function, controlling should create prerequisites for systematic collection, processing and making available information to all interested parties, primarily to internal users.

Date controlling functions can be matched to the tasks that are set before controlling as an important activity segment for modern companies, as an important guide to companies in achieving excellence, which can be shown by the following tables: 
Table 3. Interdependence of functions and tasks of controlling [4]

\begin{tabular}{|l|l|}
\hline CONTROL FUNCTIONS & \multicolumn{1}{c|}{ CONTROL } \\
TASKS
\end{tabular}

The previous table shows us in more detail on the functions and tasks of controlling and their connection to accomplishing the tasks of the company, that is, in terms of supporting the activities of enterprise management, as a fundamental task of controlling the company. From the previous table, it is possible to identify the key management tasks that are reflected in the activities of coordination, planning, management, supervision and data collection and processing as the fundamental constituents for controlling their main activities related to support to enterprise management.

When it comes to controlling, it is important to point out that in order to perform this, for an extremely important activity for the enterprise, it is necessary to provide adequate human resources, which possess adequate knowledge and skills, ie broad professional competencies that meet the requirements of this, for the company extremely important functions. In the following section we will show the following essential competences of the controller as a graphic representation:

Figure View 2. Key Controller Competencies

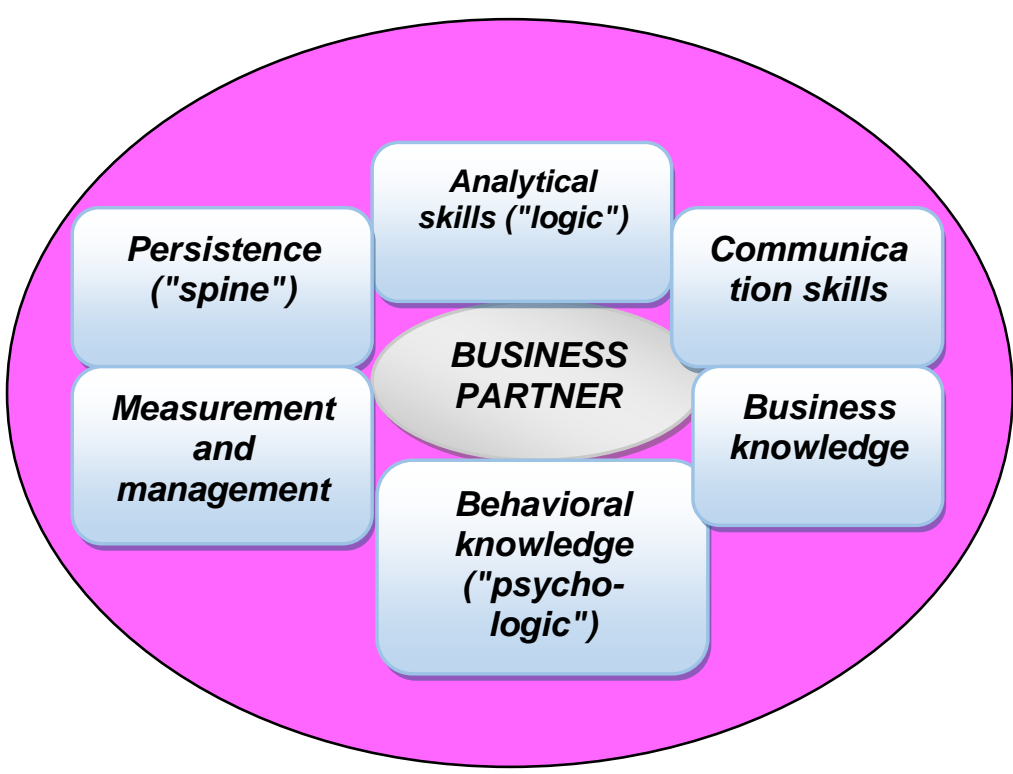

Figure 2. Key Controller Competencies [17]

Analyzing the previous graphic representation, we note that in order to perform the activities of the controllers, it is necessary to master above all the above skills, which are the basis for the successful execution of extremely complex tasks that are placed before the controllers. First of all, controllers are required to master analytical skills that enable controllers to understand and overcome issues that are contained in numerous plans, in order to adequately understand them and to allow for the identification of potential deviations from the defined plans and undertaking timely proactive activities, that is, corrective actions that need to improve the overall business of the entire enterprise. When looking at the work of controllers, it is particularly important to master adequate communication skills, because these skills are a prerequisite for the activities of controllers to be understood by stakeholders, that is, to all those who, on the basis of this information, can take proactive measures in the direction of raising the quality of total business. Since the activities of controllers are primarily oriented towards managers, it is necessary to develop a partnership relationship between them. It is important, on the one hand, that managers understand the activities of controllers and the scope of their work, and on the other hand controllers must be involved in the management activities, in order to present their results in the best way, which will be tailored to the requirements and needs of management. When it comes to controlling, it is important to point out the clear distinctions between the two areas of controlling, both stratified and operational controlling. Contemporary turbulent environment 
and increasingly prominent market survival as well as the growth and development of the company. It is precisely such market circumstances that impose the need for the development of strategic controlling that will be adequate support to the management in providing a timely response to the growing market challenges, enabling the perception of all important market trends from the impact on the company's operations. In addition to strategic controlling, as previously mentioned above, primarily focused on strategic decisions, long-term carriers, it should not be neglected even operational controlling that provides information support to management in the operationalization of strategic decisions in everyday business. On the other hand, we should not ignore the role that operational control has in business, which primarily aims at raising the efficiency of the company's operations. The activity of operational control in business practice is reflected in the permanent supply of information management that will provide professional support to the management in the realization of the set goals related to the operation of the company. In the realization of its tasks, controlling uses various mechanisms and measures such as operational planning instruments, which include operational prices, various types of screening models, comparative calculations of troposals, and the like. In order to approach this theoretically exposed matter, we will use the schematic representation below:

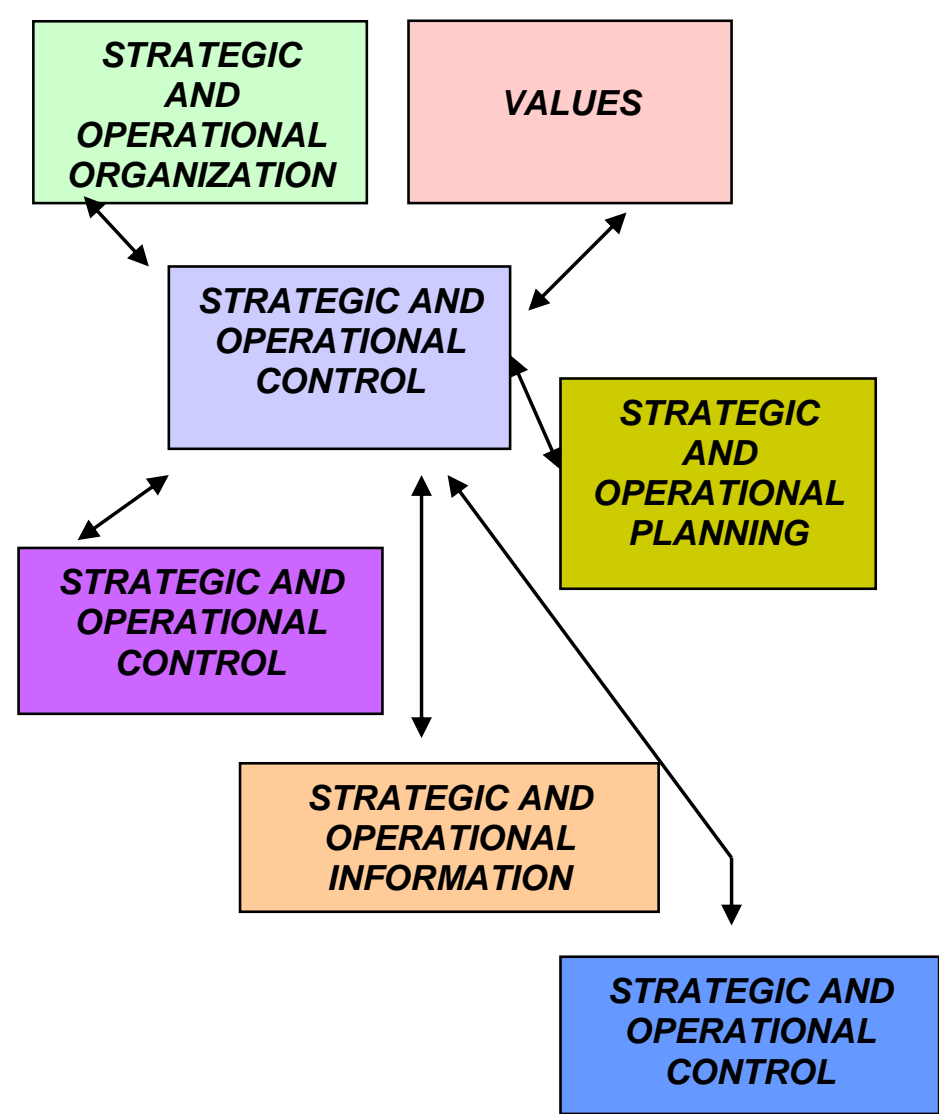

Figure 3. Strategic and operational control [8]
Analyzing previous figure 1 on the area of strategic and operational controlling, we notice some of the mechanisms that use strategic and operational control in everyday business. These mechanisms relate primarily to strategic and operational planning, strategic and operational organization, strategic and operational control and ultimately an important segment of overall controlling, which relates to strategic and operational information.

Various instruments are available for controlling their tasks. Controllers in their strategic and operational controlling activities can use a variety of instruments, and in the following we will list the five most commonly used control instruments, which will be presented in the following table:

Table 4. Strategic and operational control instruments [7]

\begin{tabular}{|c|c|}
\hline $\begin{array}{c}\text { STRATEGIC } \\
\text { CONTROL } \\
\text { INSTRUMENTS }\end{array}$ & $\begin{array}{c}\text { OPERATIVE } \\
\text { CONTROL } \\
\text { INSTRUMENTS }\end{array}$ \\
\hline $\begin{array}{c}\text { BSC - A card of } \\
\text { balanced success } \\
\text { indicators }\end{array}$ & $\begin{array}{c}\text { Methods of cost } \\
\text { management }\end{array}$ \\
\hline SWOT analysis & $\begin{array}{c}\text { Analysis of the } \\
\text { coverage point }\end{array}$ \\
\hline PESTLE analysis & $\begin{array}{c}\text { Analysis of the } \\
\text { contribution margin }\end{array}$ \\
\hline BCG matrix & $\begin{array}{c}\text { Analysis of the } \\
\text { investment budget }\end{array}$ \\
\hline Potential analysis & Analysis of the deviation \\
\hline
\end{tabular}

The BSC matrix is a complex management system focused on measuring the performance of enterprises, viewed from four perspectives: financial perspectives, customer perspective, perspectives of business processes and development prospects, thus contributing to the observation of the company's business exclusively from financial focus, because the success of an enterprise is measured through different apps like improving knowledge and skills of employees, production, motivation of employees, etc. Strategic controlling as one of its instruments uses the PEST analysis which forms the basis of strategic planning, and it refers to the analysis of the environment in which the company operates.

PEST analysis is used for an emerging market or already existing market and represents a basis for the examination of external factors that affect the business of the business branch in which the company operates or the enterprise itself. One of the controlling instruments and that of operational controlling is a contribution margin, which is also referred to as a marginal gain in economic literature, and is obtained as an outcome of sales revenue that remains with the deduction of the total amount of variable costs that include production, sales and administrative costs. The use of this indicator is extremely important in the planning of company profits. At the end of analyzing the very essence and the need for 
controlling within the company it is important to point out some important benefits that its implementation brings to the entire business. In order for the company to successfully implement the controlling concept within the company, it is necessary to have management support, that is, the management to be the carrier of activities related to the implementation of controlling in the business of the company, because without management support one can not imagine the successful development of controlling in the company. Through the implementation of controlling in the company, one can safeguard the general interest and value of the company, and on the other hand, it is necessary for the controllers to be proactive through their actions, allowing for the initiation of changes within the company.

Through the development of controlling, the management of the company receives its economic advisor, because through the controlling function it ensures that a unique stained glass consisting of a number of elements is formed, that is, the whole business of the company is focused. Also, controlling as a usefull management instrument in Crisis times [11] . Controlling should be on the one hand and a newsletter of changes, and should also provide preconditions for successful implementation of changes in the daily business practice of the company. All this actually testifies that in today's business conditions, controlling becomes a necessity, not an alternative to everyday business.

\section{IMPLEMENTATION OF CONTROLLING IN THE PUBLIC SECTOR SUBJECT - UTOPIA OR A CHALLENGE THAT CANNOT BE OBTAINED}

In the conditions of ever more pronounced and more intense market competition, business operations are becoming an imperative imposed not only on privately owned enterprises, but increasingly in the demand for companies operating in the public sector. In public sector entities, both in the domicile business environment and at the global level, we often hear the term of creating something, that is, the aspiration to create a certain value, and this often asked question does not follow the answer to how to implement it.

A strong system of supporting the implementation of public-sector enterprises defined goals in providing answers to how to create something is the implementation of controlling the concept. Although the practice of introducing controlling in a domicile business environment is only in its infancy, especially when considering the subjects of the public sector. Without the assertion of management for the actual implementation of controlling in the operations of public sector entities, and above all enterprises, this function will not accomplish the tasks that are set before it, which in fact only confirms the thesis that only in the event of full orientation of the management to the introduction of this function can contribute to the valuation its effects in the business and the transformation of its results into concrete business results. In fact, controlling gets the role of a gate that integrates all parts of the company, ie its top (management) and other parts of the body (functions of the company).

What is special value of controlling in public sector entities is that it allows increasing the efficiency, economy and efficiency of the overall public sector business, which is especially important because the public sector operates with the resources of the entire population, that is, social values.

In fact, the implementation of public sector control ensures the use of public resources in a way that is used in the function of stimulating the economy and permanently preserving the social values that this sector has. Significant benefits from the implementation of public sector control are reflected in the timely detection of latent risks, which, if they escalate, can significantly undermine the business of the company.

Since the domicile public sector is on the threshold of restructuring or has already significantly stepped into this more than a complex and challenging process, it is important to point out that there is no better and economically more efficient instrument for raising its productivity, profitability, as well as rationalizing employees and improving management structures from controlling, as research shows that the implementation of this function contributes to saving 8 to $15 \%$ of the total cost.

When we expand this percentage across the entire public sector, we clearly understand how much of the budget savings would be made at the level of one state.

Controlling and its development in public sector entities implies the development of a system that includes six basic factors, which are related to controlling as [6]: (1) a specific philosophy as part of business philosophy; (2) duties and obligations at all levels of decision-making and work; (3) linked decision-making focused on partial problems; (4) instruments used by controlling; (5) the organizational structure and the way in which the controlling is positioned therein; and (6) the breadth of knowledge, processing and the distribution and information system. In fact, through the impetus of controlling in public sector entities, it is necessary to ensure that the requirements that are set before this sector are met, and the essential preconditions for the efficient functioning of the public sector are specified by Drucker and they [2]: (1) It is necessary to define what is and what should be the job of every subject of the public sector; (2) Clear objectives from their mission definition must be implemented; (3) Priorities must be set that will enable them to set standards of production, i.e. define the minimum acceptable results, determine the deadlines and 
responsibility for the results; (4) It is necessary to define measures for monitoring the results; (5) Establish self-control by results approach to public sector entities; and (6) Revise goals that no longer serve purpose or have proved to be unachievable, identify obsolete and non-productive activities. Controlling, as a support to management in the realization of goals that should enable the increase of efficient public sector operation, can be a productive tool thanks to its instrumentation.

What is reflected in the special importance of controlling is that it allows predictions of future business events, ensuring the perception of future trends, or giving guidance to the public sector in which direction their development should be based.

Controlling in this way contributes to increasing the level of responsibility in the management of public resources, which is of particular importance to the entire population, as this way ensures more efficient management of its assets, ie the use of budgetary funds in the direction of creating benefits for all social strata. This actually indicates that controlling in public sector entities should ensure a reduction in uncertainty, a better overview of the situation and an increase in the efficiency of forecasting overall future business trends, which can be shown by the following graphic representation:

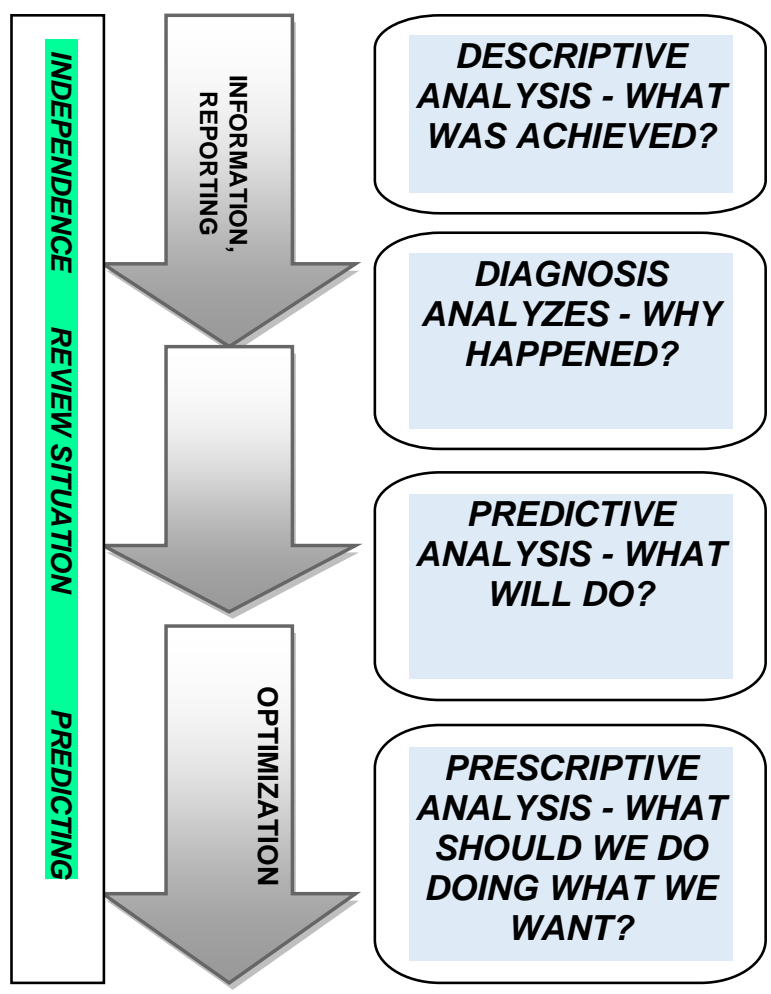

Figure 4. The role of controlling in defining the strategy of the public sector business [18]
An integral part of the controlling, which can be concluded by analyzing the previous presentation, are four analyzes, that is, controlling in public sector entities implies the implementation of these analyzes, because due to their successful implementation it allows to eliminate the unwantedness in the business, then allowing the situation in which the public sector entities operate, as well as anticipating future business trends within which public sector entities will operate. In fact, controlling through its work begins to override what and why something happened in the past, striving to find the causes, then perceiving future potential events, and helping public sector entities in defining an optimal combination of mechanisms in achieving the defined goals of public sector entities, or making business decisions that will enable the implementation of the business strategy set. Although the overriding goal of public sector entities is to satisfy the needs of citizens, as the main beneficiaries of their services, one should not overlook the fact that even these companies are expected to achieve a higher degree of efficiency, economy and efficiency in business.

Starting from the role that controlling has as a function of supporting the management in the realization of its activities, we will point to some generally accepted indicators of measuring the efficiency of the functioning of public enterprises, as a segment of the public sector:

Table number 5. Performance indicators of public enterprise performance as an integral element of the public sector [1]

\begin{tabular}{|c|c|}
\hline $\begin{array}{l}\text { FINANCIAL } \\
\text { INDICATORS }\end{array}$ & $\begin{array}{l}\text { NONFINANCIAL } \\
\text { INDICATORS }\end{array}$ \\
\hline $\begin{array}{l}\text { Profitability } \\
\text { indicators - earn } \\
\text { profits, sell products } \\
\text { and services, and data } \\
\text { on whether return is to } \\
\text { be returned to } \\
\text { shareholders }\end{array}$ & $\begin{array}{l}\text { SERVICES TO CLIENTS } \\
\text { * Customer satisfaction } \\
\text { * Services to clients } \\
\text { * Delivery results } \\
\text { * Quality of products or } \\
\text { processes } \\
\text { * Quality of service }\end{array}$ \\
\hline $\begin{array}{l}\text { Performance } \\
\text { Indicators - Measures } \\
\text { the efficiency of an } \\
\text { enterprise and to what } \\
\text { extent the enterprise } \\
\text { uses the resources at } \\
\text { its disposal. }\end{array}$ & $\begin{array}{l}\text { INNOVATION } \\
\text { * Development of new } \\
\text { products } \\
\text { * Production flexibility } \\
\text { * Technological } \\
\text { development } \\
\text { * Research and } \\
\text { development in the field of } \\
\text { productivity } \\
\text { * Innovation }\end{array}$ \\
\hline $\begin{array}{l}\text { Solvency indicators - } \\
\text { measure the } \\
\text { indebtedness of the } \\
\text { company, as well as } \\
\text { the ability to repay } \\
\text { debts. }\end{array}$ & $\begin{array}{l}\text { * Marketing Efficiency } \\
\text { * Market growth } \\
\text { * Market share }\end{array}$ \\
\hline
\end{tabular}




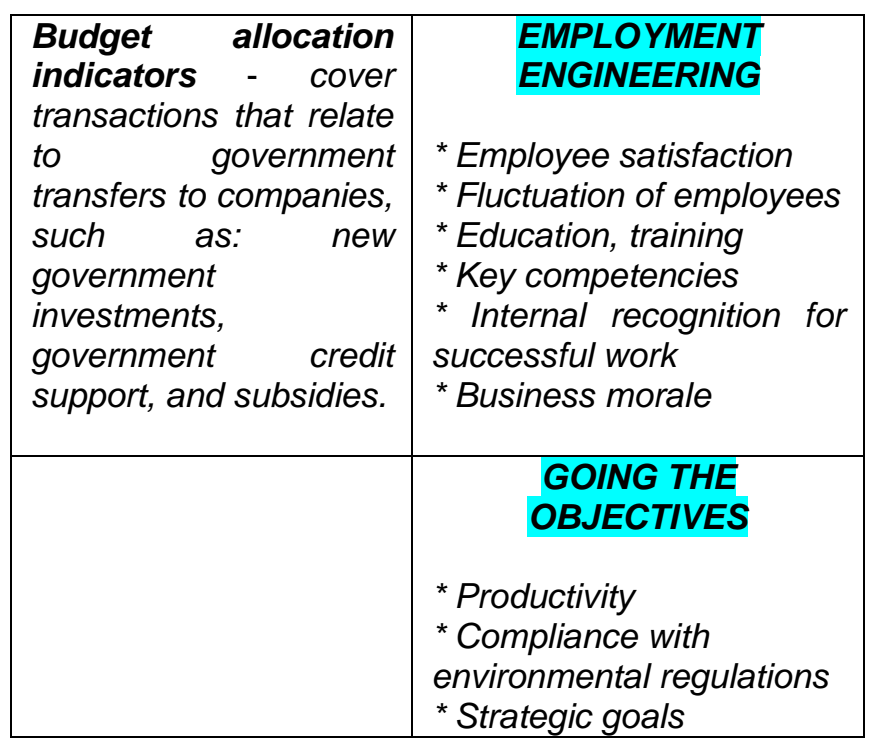

In the group of financial indicators of business performance, we can primarily identify the most commonly used four indicators, which are: profitability indicators, performance indicators, solvency indicators and budget allocation indicators.

A modern business environment is increasingly emphasizing the importance of non-financial business performance indicators, since these indicators complement the overall picture of the company's operations, giving a true picture of its performance, and these indicators relate primarily to services provided by public sector entities to their clients, or service users in the form of citizens and include indicators of citizens' satisfaction with the quality of services provided. Furthermore, within these indicators, we identify a group of indicators related to achieving the goals of organizations from the domain of the public sector, and which measures the correlation of productivity in the realization of strategic business objectives, all in the direction of realizing the activities of public sector entities in compliance with the regulatory relation on the environment.

The significance of the implementation of controlling in general, and so in the public sector entities, was also noticed by the Association of Accountants and Auditors of Serbia, which in its Conclusions from the 47th Symposium of the Association of Accountants and Auditors of Serbia underlined the need to develop control of the concept in the business of the company.

The reasons for the permanent tendency towards the introduction of a controlling concept into the company's business in Serbia stems from their inefficiency, inability to profitability, very low profit margins and low turnover, all reflected in the extremely low level of overall management process.

Through a greater information basis for decision-making by the

management of the company provided by the implementation of the controlling concept in Serbia, a significant increase in the overall quality of governance will also be ensured, which is an imperative that is posed to public sector entities.

Building an adequate controlling concept in public sector entities imposes the need to build a controller profession, which will be subject to continuous education and continuous refreshment of its knowledge, and for what should be provided adequate and well-founded educational and professional infrastructure.

An environment in which all types of companies operate, and more and more public sector enterprises involve continuous education and improvement of knowledge that employees have.

Knowledge becomes the main source of competitive and comparative advantage of the company in a modern business environment. In such circumstances, in the field of knowledge management, controlling is also its role.

Prior to controlling the knowledge of public sector entities, the following tasks are first set [21]: (1) a strategic analysis of the organization from the perspective of knowledge; (2) development of knowledge strategy and implementation of knowledge objectives; (3) building an instrument for evaluating knowledge; (4) creating knowledge-based systems and incentives.

In this sense, knowledge management in the company uses the following modules of measurement of knowledge, such as the share of employees in the company that actively acquire new knowledge and are educated, as well as in terms of the number of proposals that the employees form in order to raise the overall organizational performance of the company.

Certainly, raising professional knowledge and competencies of employees in public sector entities is one of the essential prerequisites for overall efficiency of operations, their existence, and at the same time the basis of achieving public sector tasks in terms of economy, efficiency and effectiveness.

The public sector as a whole seeks to look at a number of indicators that reflect its performance, and in whose improvement the role plays a role as controlling since it as an information support management is expected to create preconditions for their continuous improvement and raising the overall quality of life of the population of the whole country, and some of the most significant performances shows the following tables: 
Table 6. Recapitulation of the most important indicators and sub-indicators of the performance of the public sector [19]

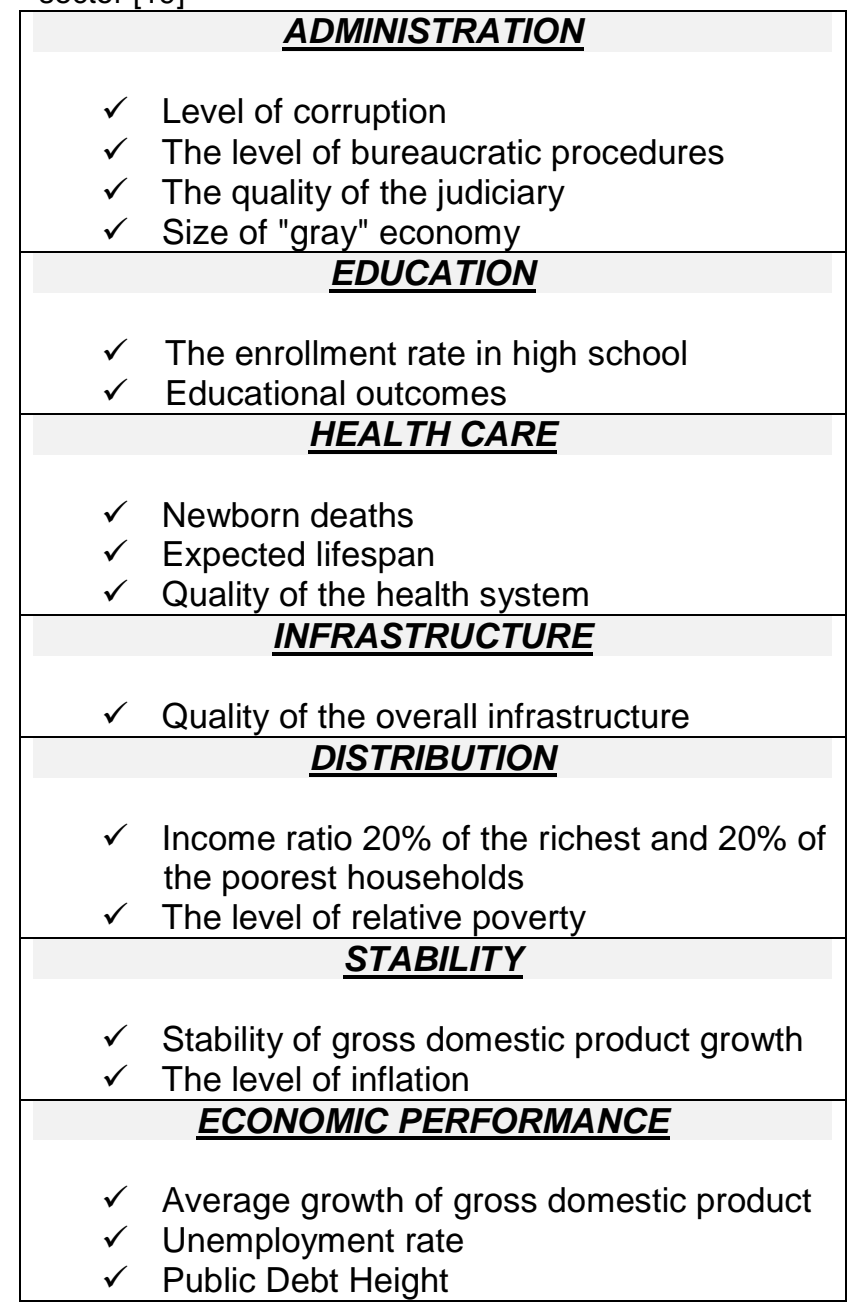

Key performance indicators that reflect the efficiency of the business of the entire public sector include the examination of the key seven areas: administration, education, health, infrastructure, distribution, stability and economic performance, as can be seen from the previous table. Each of these seven indicators reflects the performance of the overall public sector and the quality of life within a country.

Holders of public authority controlling as information support should

provide good information bases and proposals that will enable timely corrective actions in the direction of raising the quality of life of the population based on these performances.

At the end of the consideration of controlling in public sector entities, we will illustrate several areas of application that should ensure the overall quality of the work of these entities, since their work is in focus because they directly affect the quality of life of the population of a country. Some of the areas of application of public sector control are the following tables:
Table 7. Examples of the application of public sector control by area [14]

\begin{tabular}{|c|c|c|c|}
\hline PLANNING & $\begin{array}{l}\text { ANALYSIS } \\
\text { OF } \\
\text { EXECUTIO } \\
\mathbf{N}\end{array}$ & $\begin{array}{c}\text { REPORTIN } \\
\text { G }\end{array}$ & $\begin{array}{c}\text { INFLUENCE } \\
\text { TO THE } \\
\text { EXIT AND } \\
\text { PREDICTIO } \\
\mathbf{N}\end{array}$ \\
\hline $\begin{array}{c}\text { - Establish a } \\
\text { cost plan for a } \\
\text { specific period } \\
\text { in accordance } \\
\text { with an } \\
\text { accomplishmen } \\
\text { t for the } \\
\text { previous period } \\
\text { or available } \\
\text { funds }\end{array}$ & $\begin{array}{l}\text { - Costs have } \\
\text { increased in } \\
\text { relation to } \\
\text { the plan as } \\
\text { a result of } \\
\text { the } \\
\text { operation of } \\
\text { internal and } \\
\text { external } \\
\text { factors }\end{array}$ & $\begin{array}{c}\text { - Due to the } \\
\text { reduction or } \\
\text { increase of } \\
\text { costs for\% } \\
\text { or dinars in } \\
\text { relation to } \\
\text { the plan for } \\
\text { reasons ... } \\
\text { the following } \\
\text { measures } \\
\text { are } \\
\text { proposed ... } \\
\\
\text { - A deviation } \\
\text { is } \\
\text { anticipated } \\
\text { for a } \\
\text { minimum } \\
\text { of\% in the } \\
\text { period from } \\
\text {... }\end{array}$ & $\begin{array}{l}\text { - Have we } \\
\text { achieved the } \\
\text { target cost? } \\
\text { - Will it be } \\
\text { possible to } \\
\text { achieve the } \\
\text { planned } \\
\text { activities? }\end{array}$ \\
\hline $\begin{array}{l}\text { - Income plan } \\
\text { - A receipt plan }\end{array}$ & $\begin{array}{c}\text { - Reasons } \\
\text { for reducing } \\
\text { revenues } \\
\text { (receipts) } \\
\text { from the } \\
\text { budget }\end{array}$ & $\begin{array}{l}\text { - Budget } \\
\text { revenues } \\
\text { tend to } \\
\text { decline at } \\
\text { rates of } \% \\
\\
\text { - The next } \\
\text { step is } \\
\text { proposed }\end{array}$ & $\begin{array}{l}\text { - Whether it } \\
\text { will be } \\
\text { possible to } \\
\text { achieve the } \\
\text { goal by } \\
\text { taking into } \\
\text { account } \\
\text { income } \\
\text { reduction } \\
\\
\text { - What's the } \\
\text { prognosis? }\end{array}$ \\
\hline $\begin{array}{c}\text { - Plan number, } \\
\text { users, } \\
\text { programs, } \\
\text { projects, } \\
\text { activities ... }\end{array}$ & $\begin{array}{c}\text { - The } \\
\text { number of } \\
\text { users is } \\
\text { growing due } \\
\text { to the } \\
\text { impact ... }\end{array}$ & $\begin{array}{c}\text { - Number of } \\
\text { users } \\
\text { increased } \\
\text { due to ... } \\
\\
\text { - We } \\
\text { approach } \\
\text { the defined } \\
\text { target size }\end{array}$ & $\begin{array}{c}\text { - The impact } \\
\text { of an } \\
\text { increasing } \\
\text { number of } \\
\text { users on the } \\
\text { realization of } \\
\text { the goal } \\
\\
\text { - What } \\
\text { growth is } \\
\text { predicted in } \\
\text { future } \\
\text { periods }\end{array}$ \\
\hline
\end{tabular}

In the planning segment, the application of controlling is reflected in terms of cost planning for the current and future period on the basis of empirical data from the past, then in defining the plan of revenues of public sector entities, planning the number of users, programs, projects, etc.

Controlling in the report analysis segment is applied in terms of analyzing the fact that budget revenues are reduced to certain public sector entities, and then to determine the reasons for the deviations made in relation to the planned costs. 
Considering the achievement of defined target values, the cause of budget revenue decline, and the definition of corrective actions in removing certain deviations in business is a task of controlling in the domain of reporting. The latest field of application of public sector control refers to influencing the outcome of the measures taken and forecasting potential movements, which is realized through achieving the target cost, forecasting growth in the future period, and the like.

\section{CONCLUDING CONSIDERATIONS}

Building controlling is an extremely complex and complex task that is being posed before public sector entities in the future, as this is definitely one of the fundamental preconditions in reorganizing the functioning and improvement of the overall efficiency of the public sector. In order to start building controlling in enterprises, it is necessary primarily that the management understands its significance, that is, the management of a public sector entity, because only if the management has a true picture of the benefits of controlling it will be ensured its actual implementation in the public sector entities. This will enable the raising of the quality of the adopted business decisions, which will be reflected in the overall efficiency of the public sector.

Prior to controlling the public sector, a requirement is imposed not only for raising the efficiency, effectiveness and economy of the operations of public sector entities, but also its ability to adapt to internal and external changes. Since the growth of public sector efficiency is one of the firmlyestablished topics of modern society, it is clear that, in addition to numerous mechanisms focused on efficiency, such as internal audit, the role of controlling can certainly not be ignored. Controlling provides essential information support to the management of public sector entities, so its integration into the daily operations of given entities is a necessity and an objective need, and less and less exclusivity and moderation. Certainly, we can conclude that without the successful integration of controlling into the daily operations of the public sector entities, it is difficult to expect an increase in their efficiency, because they are in fact controlling and effectiveness, effectiveness and cost-effectiveness - the two sides of the same medal.

\section{LITERATURE}

[1] Crnčević llić, J. (2016), "Efikasnost funkcionisanja javnih preduzeća u Republici Srbiji", Doktorska disertacija, Univerzitet Singidunum, Fakultet za ekonomiju, finansije i administraciju, Beograd, Srbija.

[2] Drucker, P, F. (2008), Management. Revised Edition, Harper Business.

[3] Government Finance Statistics Manual, (2001), IMF, Washington, USA.
[4] Horvath, P. (2006), Kontroling, Verlag Franz Vahlen, Munchen.

[5] Lovre, I. (2015), "Analiza efikasnosti u javnom sektoru", Doktorska disertacija, Univerzitet Edukons, Sremska Kamenica, Srbija.

[6] Luković, T., Lebefromm, U. (2009), Kontroling - koncepcija i slučajevi, Sveučilište u Dubrovniku, Dubrovnik, Hrvatska.

[7] Meter, M., Šarčević, M. (2017), Primjena instrumenata kontrolinga u praksi hrvatskih poduzeća, Kontroling u praksi - instrumenti kontrolinga, Poslovna učinkovitost d.o.o. za poslovno savjetovanje, Zagreb, Hrvatska.

[8] Osmanagić Bedenik, N. (2004), Kontroling - abeceda poslovnog uspjeha, Školska knjiga, Zagreb, Hrvatska.

[9] Paunović, B. (2009), "Privatizaija javnih preduzeća u Srbiji", Doktorska disertacija, Univerzitet Singidunum, Beograd. Srbija.

[10] Perović, V. (2004), "Kontroling Koncept preduzeća", Privredna izgradnja, XLVII: 1-2, str. 113-135.

[11] Perović, V., Nerandžić, B., Todorović, A. (2012), "Controlling as a usefull management instrument in Crisis times", African Journal of Business Management Vol. 6, pp. $2101-2106$.

[12] Perović, V., Nerandžić, B., Bojanić, R., Štrbac, M. (2012), "Perspektive razvoja kontrolinga kao naučne discipline". Zbornik radova II konferencije „Kontroling i interna revizija“, Fakultet tehničkih nauka, Novi Sad, str. 1 - 5.

[13] Štiglic, DŽ. (2013), Ekonomija javnog sektora, Ekonomski fakultet, Beograd, Srbija.

[14] Vitezić, N. (2017), "Kontroling u javnom sektoru", Računovodstvo, revizija i financije, prilog, broj 5, RRIF plus, Zagreb.

[15] Zvanična internet prezetnacija Narodne banke Srbije: www.nbs.rs.

[16] Zvanična internet prezentacija Fakulteta organizacionih nauka u Beogradu: www. fon.bg.ac.rs.

[17] Zvanična internet prezentacija Kontroler akademije: www.icv-controlling.com.

[18] Zvanična internet prezentacija portala "Moja firma": www.mojafirma.rs.

[19] Zvanična internet prezentacija „Libeka“: www.libek.org.rs

[20] Ziegenbein, K. (2008), Kontroling, deveto prerađeno i aktuleno izdanje, RRiF Zagreb, Hrvatska 


\title{
Kontrola fiskalne odgovornosti - Dve putanje do istog cilja
}

\author{
Marijana Cupać, Saša Gravorac, Dejan Gligović, Goran Šijan
}

Primljen (11.12.2018.); Recenziran (19.01.2019.); Prihvaćen (14.02.2019.)

\begin{abstract}
Abstrakt
Proces privatizacije i odlučnost Srbije da se pridruži Evropskoj uniji, kao i rastuća ekonomska kriza i tržišna konkurencija kao faktori egzogene prirode, nametnuli su i potrebu stvaranja instrumenta pred privatnim sektorom kao i pred javnim sektorom koji će prevazići rastuće tržišne izazove, koji se neizbežno nameću i privatnim ali i subjektima javnog sektora. Pored osnovne uloge, koja se ogleda u pružanju kvalitetnih usluga svojim glavnim potrošačima - stanovništvu, zahtevi viših fiskalnih vlasti za štednju, povećanje efikasnosti $i$ efektivnosti poslovanja, kao $i$ ostvarivanje profita, sve se više postavljaju pred upravljanje javnim preduzećima. Povećanje orijentacije javnog sektora prema tržišnim principima poslovanja, nametnulo je javnom sektoru implementaciju nekih tradicionalnih tržišnih mehanizama koji se koriste u funkciji podizanja ukupne profitabilnosti poslovanja, a time i potražnje za permanentnom edukacijom menadžmenta $i$ zaposlenih u funkciji ovladavanja $i$ implementacije tradicionalnih tržišnih instrumenata u pravcu veće efikasnosti javnih preduzeća. $U$ radu će se analizirati pojam i karakteristike javnog sektora, osnovna priroda $i$ suština kontrolinga, proces implementacije kontrolinga u subjektima javnog sektora i nivo razvoja kontrolinga u javnom sektoru Republike Srbije.
\end{abstract}

Ključne reči: javni sektor, fiskalna odgovornost, kontroling, efikasnost, učinak 